\title{
RANCANG BANGUN SISTEM PENDUKUNG KEPUTUSAN PENERIMAAN KARYAWAN BARU DENGAN MENGGUNAKAN METODE SIMPLE ADDITIVE WEIGHTING (SAW) BERBASIS WEB DI LOSE STORE
}

\author{
Hengki Rusdianto \\ Program Studi Informatika \\ Fakultas Teknik Universitas Muhammadiyah Tangerang \\ J1. Perintis Kemerdekaan 1/33 Cikokol Kota Tangerang \\ Hengki.rusdianto@gmail.com
}

\begin{abstract}
Recruitment is an important thing for the company, in acquiring prospective new employees to occupy a position. Most companies, recruitment process is still not done by a professional. This happens because there is no systematic method to assess the feasibility of prospective new employees. Recruitment decision support system applications are built using the Simple Additive Weighting (SAW) method. This method was chosen because it can determine the weight values for each attribute, and then proceed with the ranking process that will select the best alternative from several alternatives. In this case, the alternative is entitled to be accepted as a new employee in accordance with the criteria specified. Based on test results, a system built to simplify and speed up the selection process for recruitment, and assist Human Resources Department (HRD) managers in decision-making to determine a new employee at a company.
\end{abstract}

Keywords : Decision Support Systems, Recruitment, Criteria, Simple Additive Weighting (SAW).

\section{PENDAHULUAN}

\subsection{Latar belakang}

Pada masa ini teknologi dan informasi sangat berperan penting guna menunjang aktivitas sehari-hari, baik dalam dunia bisnis, hiburan, Pendidikan, pemerintahan dan lain sebagainya. Informasi dapat digunakan untuk membantu pengambilan keputusan dalam system pendukung keputusan (Decision Support System). Salah satu contoh, dalam praktek seleksi penerimaan karyawan baru di Lose Store dimana profesional dalam penerimaan karywan baru sangat di perlukan, banyak hal bisa terjadi dalam proses penerimaan karyawan baru jika hanya mengandalkan diterima karena adanya hubungan keluarga, pertemanan ataupun penyuapan. Selain itu kecepatan dan keakuratan data sangat diperlukan dalam pengambilan keputusan dalam proses seleksi karyawan.

Melihat fenomena tersebut peran divisi Sumber Daya Manusia (SDM) dalam menangani permasalahan penerimaan karyawan baru dinilai masih belum maksimal. Peran divisi Sumber Daya Manusia (SDM) terutama manajer yang melakukan seleksi sangat dibutuhkan sejak awal dalam proses penerimaan karyawan baru. Karena dari awal proses inilah kemudian para calon karywan akan diberikan bekal dan perisapan untuk bekerja di suatu perusahaan.

\subsection{Batasan masalah}

Berdasarkan dengan penelitian dan pembahasan yang dilakukan, penulis membatasi masalah pada proses seleksi karyawan baru di Lose Store, yaitu meliputi

1. Sistem informasi yang di buat hanya meliputi sistem pendukung keputusan penerimaan karyawan baru.

2. Kriteria yang digunakan untuk penerimaan calon karyawan baru di Lose Store, yaitu :
a. Pengalaman kerja
b. Pendidikan 

c. Usia
d. Status
e. Alamat

3. Bahasa pemrograman yang digunakan adalah Hypertext Preprocessor (PHP).

4. Metode yang digunakan dalam seleksi karyawan baru dibatasi pada metode Simple Additive Weighting (SAW).

\section{TINJAUAN PUSTAKA}

\subsection{Sistem Pendukung Keputusan}

Menurut Siswanti (2015) Sistem Pendukung Keputusan atau Decision Support System (DSS) adalah suatu sistem yang ditunjukan untuk mendukung manajemen pengambilan keputusan dimana sistem berbasis model yang terdiri dari prosedur-prosedur dalam pemrosesan data dan pertimbangannya untuk membantu manajer dalam mengambil keputusan.

Tujuan dari sistem pendukung keputusan Kusrini (2007) adalah sebagai berikut :

1. Membantu manajer dalam mengambil keputusan atau masalah semi struktur

2. Memberikan dukungan atas pertimbangan manajer dan bukannya dimaksudkan untuk menggantikan fungsi manajer.

\subsection{Simple Additive Weighting (SAW)}

Metode SAW sering dikenal dengan istilah metode penjumlahan terbobot. Konsep dasar metode SAW (Simple Additive Weighting) adalah mencari penjumlahan terbobot dari rating kinerja pada setiap alternatif pada semua atribut(Fishburn, 1967) (MacCrimmon, 1968).

Metode SAW membutuhkan proses normalisasi matriks keputusan (X) ke suatu yang dapat diperbandingkan dengan semua rating alternatif yang ada.

$$
r_{i j}=\left\{\begin{array}{l}
\frac{x_{i j}}{\operatorname{Max} x_{i j}} \text { Jika } j \text { adalah atribut keuntungan (benefit) } \\
\frac{\operatorname{Min}_{i} x_{i j}}{x_{i j}} \text { Jika } j \text { adalah atribut biaya (cost) }
\end{array}\right.
$$

Rij $\quad$ : Rating kinerja ternomalisasi

Maxi : Nilai maksimum dari setiap baris dan

Mini : Nilai minimum dari setiap baris dan kolom

Xij : Baris dan kolom dari matriks
Dimana rij adalah kinerja ternormalisasi dari alternnatif Ai pada atribut $\mathrm{Cji}=1,1 \ldots, \mathrm{m}$ dan $\mathrm{j}=$ $1,2 \ldots, \mathrm{m}$.

Nilai preferensi altternatif (Vi) diberikan sebagai

$$
V_{i}=\sum_{j=1}^{\substack{V_{i} \\ n}} w_{j} r_{i j}
$$

Vi : Nilai Akhir Alternatif

Wi : Bobot yang telah ditentukan

Rij : Normalisasi matriks

Nilai V yang lebih besar, mengindikasikan bahwa alternatif Ai llebih terpilih.

\subsection{Unifield Modeling Languange}

Menurut Nugroho (2010) "UML (Unified Modeling Language) adalah bahasa pemodelan untuk sistem atau perangkat lunak yang berparadigma (berorientasi objek)." Pemodelan (modeling) sesungguhnya digunakan untuk penyederhanaan permasalahan-permasalahan yang kompleks sedemikian rupa sehingga lebih mudah dipelajari dan dipahami.

\section{METODOLOGI PENELITIAN}

\subsection{Jenis Penelitian}

Jenis penelitian digunakan oleh penulis untuk mendapatkan data sebagai bahan kajian dalam penulisan skripsi dengan tujuan membuat suatu Rancang Bangun Sistem Pendukung Keputusan Penerimaan Karyawan Baru di Lose Sore Menggunakan Metode Simple Additive Weighting. Dalam hal ini penulis menggunakan metode pengumpulan data berupa sumber data primer (observasi, wawancara, dan pengamatan sistem) dan sumber data sekunder (dokumentasi). Jenis pengumpulan data yang dapat dikategorikan sebagai berikut :

1. Data primer

Teknik observasi yaitu dengan melakukan pengamatan dan perencanaan secara langsung. Dengan observasi maka kita dapat memperoleh data pendahuluan yang nantinya akan menjadi faktor penentu dalam membuat suatu perumusan masalah. 
Dalam pelaksanaan observasi dilakukan dengan bertanya langsung kepada owner Lose Store yaitu Widodo.

2. Data sekunder

Dalam menyelesaikan laporan ini, data diperoleh dari media pustaka tentang teoriteori sistem yang digunakan dalam pembuatan Sistem Pendukung Keputusan Peneriman Keryawan Baru di Lose Store dengan Metode Simple Additive Weighting. Sistem ini menggunakan bahasa pemrograman Hypertext Processor (PHP) sehingga dapat dijadikan sistem yang baru sesuai dengan kaidah-kaidah sistem yang benar.

\subsection{Metode Analisa dan Perancangan}

Sebagaimana yang telah diuraikan pada bab satu, dalam Rancang Bangun Sistem Pendukung Keputusan Penerimaan Karyawan Baru di Lose Store Berbasis Web. Penulis menggunakan metode pengembangan sistem dengan model proses SDLC Waterfall. Yang merupakan model klasik sederhana, terstruktur dan bersifat sekuensial linear, karena prosesnya mengalir begitu saja, mulai dari awal hingga akhir (Pressman, 2012).

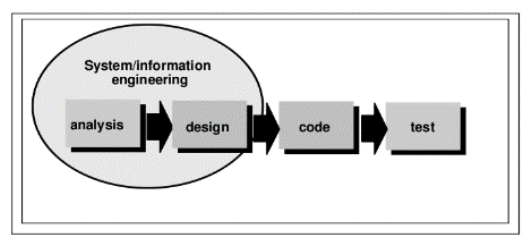

Gambar 3.1 Model Waterfall

Dalam pengembangannya metode Waterfall memiliki beberapa tahapan yang berurutan yaitu

1. Analisis kebutuhan sistem (Penilaian)

2. Desain sistem (Design system)

3. Pengkodean (coding)

4. Pengujian (Testing)

\subsection{Analisa Kebutuhan Sistem}

Analisa sistem merupakan suatu tahap pemahaman proses yang bertujuan untuk mengetahui proses apa saja yang terlibat dalam sistem dan berhubungan satu proses dengan proses lainnya. Dari pemahaman proses tersebut maka dapat dilakukan suatu evaluasi dan usulan terhadap sistem yang ada, untuk dikembangkan labih lanjut.

\section{HASIL DAN PEMBAHASAN}

\subsection{Analisa Kebutuhan Sistem}

Kebutuhan sistem dalam penelitian ini dengan langkah Penyelesaian Simple Additive Weighting (SAW) sebagai berikut

1. Menentukan kriteria-kriteria yang akan dijadikan acuan dalam pengambilan keputusan, yaitu $\mathrm{Ci}$.

2. Menentukan rating kecocokan setiap alternatif pada setiap kriteria.

3. Membuat matriks keputusan berdasarkan kriteria (Ci), melakukan normalisasi matriks berdasarkan persamaan yang disesuaikan dengan jenis atribut (atribut keuntungan ataupun atribut biaya) sehingga diperoleh matriks ternormalisasi R.

Pada penelitian ini penyeleksi penerimaan keryawan baru untuk mengisi perkerjaan di divisi desain dengan menggunakan metode SAW. Diperlukan kriteria dan bobot untuk melakukan perhitungan sehingga akan didapat alternatif terbaik. Dari beberapa calon telah dibuatkan tabel nilai, kriteria, alternatif serta bobot sebagai berikut :

Tingkat kepentingan setiap kriteria, juga dinilai dengan 1 sampai 5, yaitu :

Tabel 4.1 Nilai

\begin{tabular}{|l|l|}
\hline Nilai & \multicolumn{1}{c|}{ Keterangan Nilai } \\
\hline 1 & Sangat kurang \\
\hline 2 & Kurang \\
\hline 3 & Cukup \\
\hline 4 & Baik \\
\hline 5 & Sangat Baik \\
\hline
\end{tabular}

Kriteria yang digunakan sebagai acuan ada 5 yaitu : 
Tabel 4.2 Kriteria

\begin{tabular}{|l|l|}
\hline \multicolumn{1}{|c|}{ Kode } & \multicolumn{1}{c|}{ Kriteria } \\
\hline C1 & Pengalaman Kerja \\
\hline C2 & Pendidikan \\
\hline C2 & Usia \\
\hline C4 & Status \\
\hline C5 & Alamat \\
\hline
\end{tabular}

Dari lowongan pekerjaan tersebut didapatkan 7 alternatif yang melamar, data berupa tabelnya sebagai berikut :

Tabel 4.3 Alternatif

\begin{tabular}{|l|l|}
\hline \multicolumn{1}{|c|}{ Kode } & \multicolumn{1}{c|}{ Alternatif } \\
\hline A1 & Doni \\
\hline A2 & Rafli \\
\hline A3 & Hariri \\
\hline A4 & Wahyu \\
\hline A5 & Rizki \\
\hline A6 & Nuraini \\
\hline A7 & Sari \\
\hline
\end{tabular}

Langkah - langkah penyelesaian :

1. Memberikan nilai pada setiap alternatif dan kriteria yang sudah ditentukan. Tabel dibawah ini menunjukan data penilaian dari setiap alternatif pada setiap kriteria.

Tabel 4.4 Data Penilaian

\begin{tabular}{|l|c|c|c|c|c|}
\hline \multirow{2}{*}{ Alter } & \multicolumn{5}{|c|}{ Kriteria } \\
\cline { 2 - 6 } & C1 & C2 & C3 & C4 & C5 \\
\hline A1 & 1 & 4 & 4 & 3 & 2 \\
\hline A2 & 2 & 3 & 4 & 3 & 2 \\
\hline A3 & 1 & 4 & 4 & 3 & 2 \\
\hline A4 & 2 & 3 & 4 & 4 & 1 \\
\hline A5 & 1 & 4 & 4 & 3 & 4 \\
\hline A6 & 1 & 2 & 3 & 1 & 1 \\
\hline A7 & 2 & 1 & 3 & 5 & 3 \\
\hline
\end{tabular}

Berdasarkan Tabel 4.4 diatas, dapat di bentuk matriks keputusan $\mathrm{X}$ sebagai berikut:

$$
\times=\left[\begin{array}{lllll}
1 & 4 & 4 & 3 & 2 \\
2 & 3 & 4 & 3 & 2 \\
1 & 4 & 4 & 3 & 2 \\
2 & 3 & 4 & 4 & 1 \\
1 & 4 & 4 & 3 & 4 \\
1 & 2 & 3 & 1 & 1 \\
2 & 1 & 3 & 5 & 3
\end{array}\right]
$$

2. Memberikan Nilai bobot (W)

Untuk menentukan bobot pada divisi desain di bentuk dalam table di bawah ini :

Tabel 4.5 Bobot divisi desain

\begin{tabular}{|l|l|}
\hline Kriteria & \multicolumn{1}{|c|}{ Bobot } \\
\hline C1 & 30 \\
\hline C2 & 25 \\
\hline C2 & 15 \\
\hline C4 & 20 \\
\hline C5 & 10 \\
\hline
\end{tabular}

$\mathrm{W}=[30,25,15,20,10]$

3. Normalisasi matrik X menjadi $\mathrm{R}$ :

$$
r_{i j}=\left\{\begin{array}{l}
\frac{x_{i j}}{\operatorname{Max} x_{i j}} \text { Jika } j \text { adalah atribut keuntungan (benefit) } \\
\frac{\operatorname{Min}_{i} x_{i j}}{x_{i j}} \text { Jika } j \text { adalah atribut biaya (cost) }
\end{array}\right.
$$

a. Kriteria Pengalaman kerja, atribut keuntungan (benefit)

$$
\begin{aligned}
& \mathrm{R} 11=\frac{1}{\max (1 ; 2 ; 1 ; 2 ; 1 ; 1 ; 2)}=\frac{1}{2}=0.5 \\
& \mathrm{R} 21=\frac{2}{\max (1 ; 2 ; 1 ; 2 ; 1 ; 1 ; 2)}=\frac{2}{2}=1 \\
& \mathrm{R} 31=\frac{1}{\max (1 ; 2 ; 1 ; 2 ; 1 ; 1 ; 2)}=\frac{1}{2}=0.5 \\
& \mathrm{R} 41=\frac{2}{\max (1 ; 2 ; 1 ; 2 ; 1 ; 1 ; 2)}=\frac{2}{2}=1 \\
& \mathrm{R} 51=\frac{1}{\max (1 ; 2 ; 1 ; 2 ; 1 ; 1 ; 2)}=\frac{1}{2}=0.5 \\
& \mathrm{R} 61=\frac{1}{\max (1 ; 2 ; 1 ; 2 ; 1 ; 1 ; 2)}=\frac{1}{2}=0.5 \\
& \mathrm{R} 71=\frac{2}{\max (1 ; 2 ; 1 ; 2 ; 1 ; 1 ; 2)}=\frac{2}{2}=1
\end{aligned}
$$

b. Kriteria Pendidikan, atribut keuntungan(benefit)

$$
\mathrm{R} 12=\frac{4}{\max (4 ; 3 ; 4 ; 3 ; 4 ; 2 ; 1)}=\frac{4}{4}=1
$$




$$
\begin{gathered}
\mathrm{R} 22=\frac{3}{\max (4 ; 3 ; 4 ; 3 ; 4 ; 2 ; 1)}=\frac{3}{4}=0.75 \\
\mathrm{R} 32=\frac{4}{\max (4 ; 3 ; 4 ; 4 ; 4 ; 2 ; 1)}=\frac{4}{4}=1 \\
\mathrm{R} 42=\frac{3}{\max (4 ; 3 ; 4 ; 3 ; 4 ; 2 ; 1)}=\frac{3}{4}=0.75 \\
\mathrm{R} 52=\frac{4}{\max (4 ; 3 ; 4 ; 3 ; 4 ; 2 ; 1)}=\frac{4}{4}=1 \\
\mathrm{R} 62=\frac{2}{\max (4 ; 3 ; 4 ; 3 ; 4 ; 2 ; 1)}=\frac{2}{4}=0.5 \\
\mathrm{R} 72=\frac{1}{\max (4 ; 3 ; 4 ; 3 ; 4 ; 2 ; 1)}=\frac{1}{4}=0.25
\end{gathered}
$$

c. Kriteria Usia, atribut keuntungan (benefit)

$$
\begin{aligned}
\mathrm{R} 13 & =\frac{4}{\max (4 ; 4 ; 4 ; 4 ; 4 ; 3 ; 3)}=\frac{4}{4}=1 \\
\mathrm{R} 23 & =\frac{4}{\max (4 ; 4 ; 4 ; 4 ; 4 ; 3 ; 3)}=\frac{4}{4}=1 \\
\mathrm{R} 33 & =\frac{4}{\max (4 ; 4 ; 4 ; 4 ; 4 ; 3 ; 3)}=\frac{4}{4}=1 \\
\mathrm{R} 43 & =\frac{4}{\max (4 ; 4 ; 4 ; 4 ; 4 ; 3 ; 3)}=\frac{4}{4}=1 \\
\mathrm{R} 53 & =\frac{4}{\max (4 ; 4 ; 4 ; 4 ; 4 ; 3 ; 3)}=\frac{4}{4}=1 \\
\mathrm{R} 63 & =\frac{3}{\max (4 ; 4 ; 4 ; 4 ; 4 ; 3 ; 3)}=\frac{3}{4}=0.75 \\
\mathrm{R} 73= & \frac{3}{\max (4 ; 4 ; 4 ; 4 ; 4 ; 3 ; 3)}=\frac{3}{4}=0.75
\end{aligned}
$$

d. Kriteria Status, atribut biaya (cost)

$$
\begin{aligned}
& \mathrm{R} 14=\frac{\min (3 ; 3 ; 3 ; 4 ; 3 ; 1 ; 5)}{3}=\frac{1}{3}=0.33 \\
& \mathrm{R} 24=\frac{\min (3 ; 3 ; 3 ; 4 ; 3 ; 1 ; 5)}{3}=\frac{1}{3}=0.33 \\
& \mathrm{R} 34=\frac{\min (3 ; 3 ; 3 ; 4 ; 3 ; 1 ; 5)}{3}=\frac{1}{3}=0.33 \\
& \mathrm{R} 44=\frac{\min (3 ; 3 ; 3 ; 4 ; 3 ; 1 ; 5)}{4}=\frac{1}{4}=0.25 \\
& \mathrm{R} 54=\frac{\min (3 ; 3 ; 3 ; 4 ; 3 ; 1 ; 5)}{3}=\frac{1}{3}=0.33 \\
& \mathrm{R} 64=\frac{\min (3 ; 3 ; 3 ; 4 ; 3 ; 1 ; 5)}{1}=\frac{1}{1}=1 \\
& \mathrm{R} 74=\frac{\min (3 ; 3 ; 3 ; 4 ; 3 ; 1 ; 5)}{5}=\frac{1}{5}=0.2
\end{aligned}
$$

e. Kriteria Alamat, atribut biaya (cost)

$$
\begin{aligned}
& \mathrm{R} 15=\frac{\min (2 ; 2 ; 2 ; 1 ; 4 ; 1 ; 3)}{2}=\frac{1}{2}=0.5 \\
& \mathrm{R} 25=\frac{\min (2 ; 2 ; 2 ; 1 ; 4 ; 1 ; 3)}{2}=\frac{1}{2}=0.5 \\
& \mathrm{R} 35=\frac{\min (2 ; 2 ; 2 ; 1 ; 4 ; 1 ; 3)}{2}=\frac{1}{2}=0.5
\end{aligned}
$$

$$
\begin{aligned}
& \mathrm{R} 45=\frac{\min (2 ; 2 ; 2 ; 1 ; 4 ; 1 ; 3)}{1}=\frac{1}{1}=1 \\
& \mathrm{R} 55=\frac{\min (2 ; 2 ; 2 ; 1 ; 4 ; 1 ; 3)}{4}=\frac{1}{4}=0.25 \\
& \mathrm{R} 65=\frac{\min (2 ; 2 ; 2 ; 1 ; 4 ; 1 ; 3)}{1}=\frac{1}{1}=1 \\
& \mathrm{R} 75=\frac{\min (2 ; 2 ; 2 ; 1 ; 4 ; 1 ; 3)}{3}=\frac{1}{3}=0.33
\end{aligned}
$$

Dari persamaan normalisasi matriks X di peroleh matriks R sebagai berikut :

$$
R=\left[\begin{array}{ccccc}
0.5 & 1 & 1 & 0.33 & 0.5 \\
1 & 0.75 & 1 & 0.33 & 0.5 \\
0.5 & 1 & 1 & 0.33 & 0.5 \\
1 & 0.75 & 1 & 0.25 & 1 \\
0.5 & 1 & 1 & 0.33 & 0.25 \\
0.5 & 0.5 & 0.75 & 1 & 1 \\
1 & 0.25 & 0.75 & 0.2 & 0.33
\end{array}\right]
$$

4. Melakukan proses perangkingan dengan menggunakan bobot yang telah diberikan oleh pengambil keputusan $\mathrm{W}=[30,25,15$, 20, 10]

$$
V_{i}=\sum_{j=1}^{\substack{V_{i} \\ n}} w_{j} r_{i j}
$$

$$
\begin{aligned}
\mathrm{V}_{1}= & (30)(0.5)+(25)(1)+(15)(1)+(20)(0.33) \\
& +(10)(0.5)=66.67 \\
\mathrm{~V}_{2}= & (30)(1)+(25)(0.75)+(15)(1)+(20)(0.33) \\
& +(10)(0.5)=75.41 \\
\mathrm{~V}_{3}= & (30)(0.5)+(25)(1)+(15)(1)+(20)(0.33) \\
& +(10)(0.5)=66.67 \\
\mathrm{~V}_{4}= & (30)(1)+(25)(0.75)+(15)(1)+(20)(0.25) \\
& +(10)(1)=78.75 \\
\mathrm{~V}_{5}= & (30)(0.5)+(25)(1)+(15)(1)+(20)(0.33) \\
& +(10)(0.25)=64.17 \\
\mathrm{~V}_{6}= & (30)(0.5)+(25)(0.5)+(15)(0.75)+(20)(1) \\
& +(10)(1)=68.75 \\
\mathrm{~V}_{7}= & (30)(1)+(25)(0.25)+(15)(0.75)+ \\
& (20)(0.2)+(10)(0.33)=54.84
\end{aligned}
$$

Kesimpulan, yang terpilih untuk di terima sebagai karyawan baru adalah $\mathrm{V}_{4}$ yaitu Wahyu $\left(\mathrm{A}_{4}\right)$ karena memiliki nilai freperensi yang lebih tinggi dibandingkan dengan yang lain. 
Dari hasil perhitungan menggunakan metode SAW dapat di buatkan tabel dengan standar nilai penerimaan karyawan baru di Lose Store, standar nilai yaitu $0-50$ tidak lulus, $50-70$ Review kembali, 70 - 100 lulus. Dan tabelnya sebagai berikut :

Tabel 4.6 Hasil Perhitungan SAW
\begin{tabular}{|l|r|l|}
\hline \multicolumn{1}{|c|}{ Nama } & \multicolumn{1}{c|}{ Nilai } & \multicolumn{1}{c|}{ Keterangan } \\
\hline Wahyu & 78.75 & Lulus \\
\hline Rafli & 75.41 & Lulus \\
\hline Nuraini & 68.75 & Review kembali \\
\hline Doni & 66.66 & Review kembali \\
\hline Hariri & 66.66 & Review kembali \\
\hline Rizki & 64.16 & Review kembali \\
\hline Sari & 54.83 & Review kembali \\
\hline
\end{tabular}

\subsection{Perancangan Sistem usulan}

Perancangan sistem atau desain sistem dilakukan apabila tahap dan analisis sistem telah selesai dilakukan. Berdasarkan pada hasil analisis sistem. maka diusulkan perancangan sistem baru, dimana kinerja dari suatu sistem yang baru diharapkan dapat mengatasi beberapa permasalahan yang ada sebelumnya. Dalam menganalisa usulan sistem menggunakan diagram UML yaitu: Use case diagram, Statechart diagram, Activity diagram, Sequence diagram, dan Class diagram.

\section{Usecase diagram}

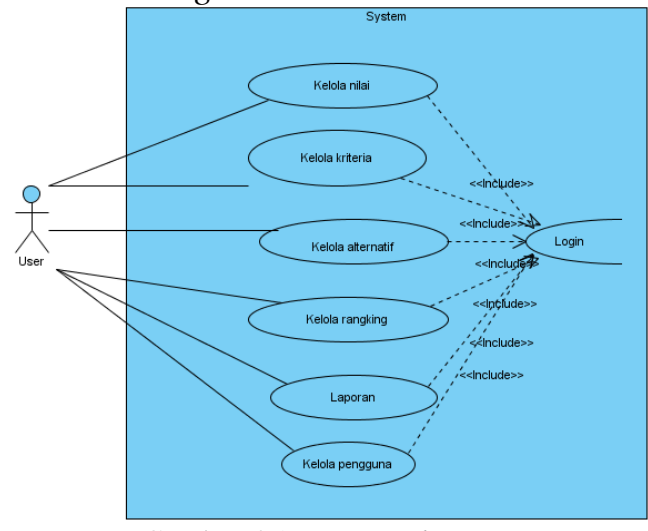

Gambar 4.1 Usecase diagram

\section{Statechart diagram}

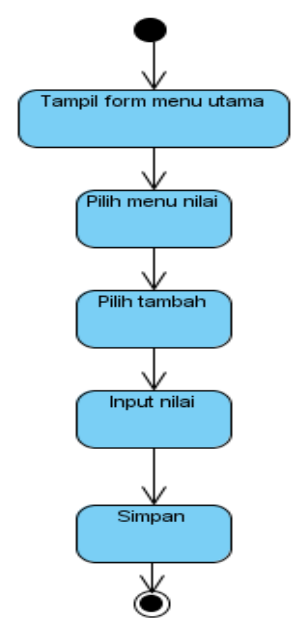

Gambar 4.2 Statechart diagram nilai

3. Activity diagram

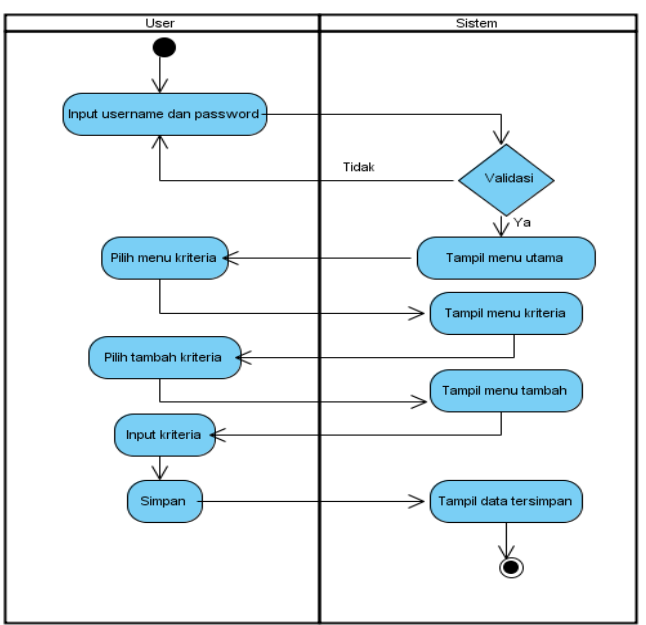

Gambar 4.3 Activity diagram kriteria 


\section{Sequence diagram}

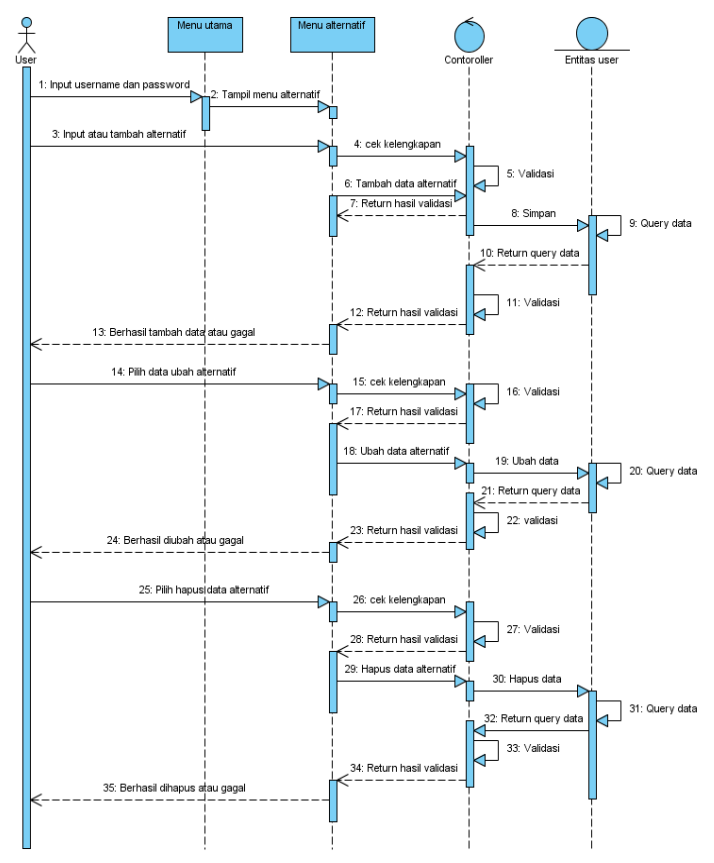

Gambar 4.4 Sequence diagram alternatif

5. Class diagram

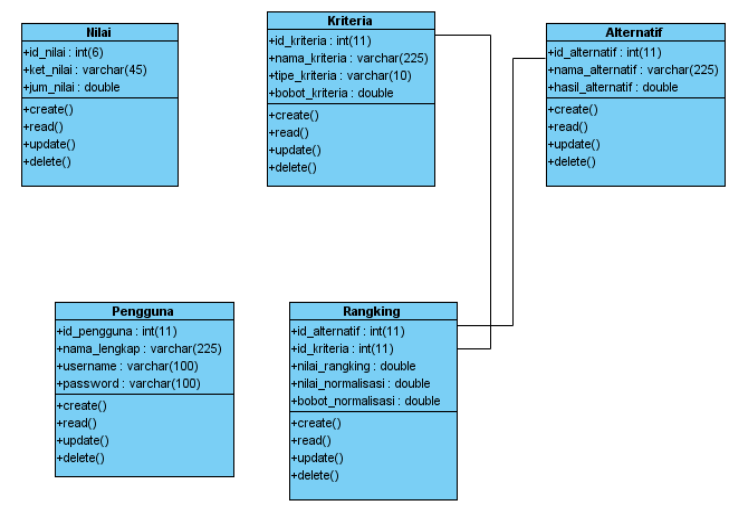

Gambar 4.5 Class diagram

\subsection{Implementasi sistem}

Implementasi adalah penerapan hasil rancangan yang telah dibuat dari beberapa kode program menjadi suatu aplikasi. Pada tahap ini aplikasi yang telah dianalisis dan dirancang akan berfungsi dan berjalan dengan baik. Aplikasi ini diimpelementasikan dari desain dan kode.
1. Menu home

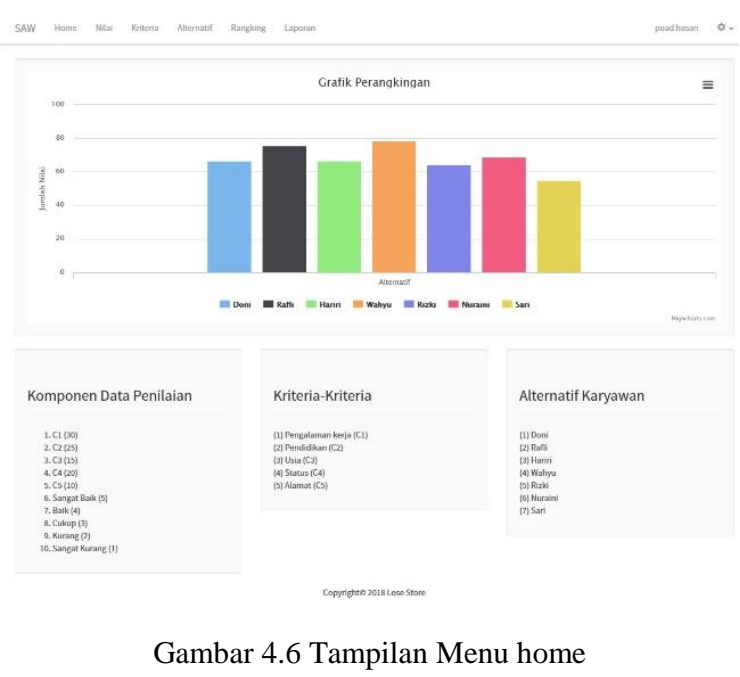

2. Menu nilai

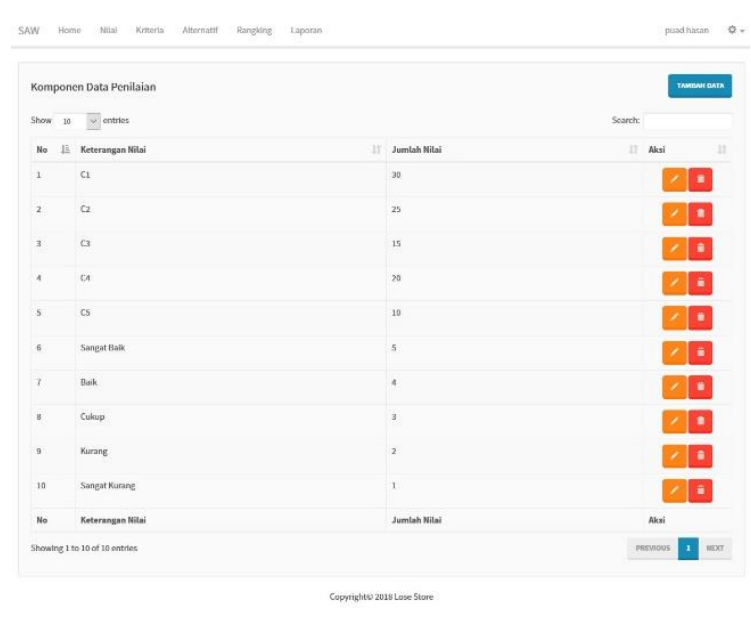

Gambar 4.7 Tampilan menu nilai

3. Menu kriteria

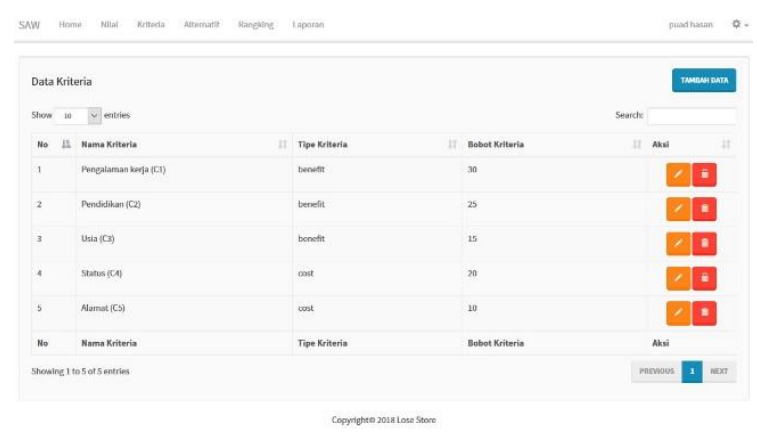

Gambar 4.8 Tampilan menu kriteria 
4. Menu alternatif

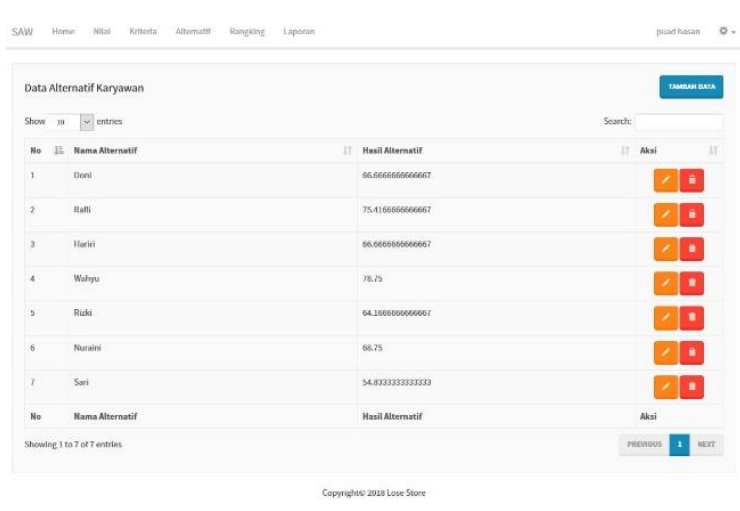

Gambar 4.9 Tampilan menu alternatif

5. Menu rangking

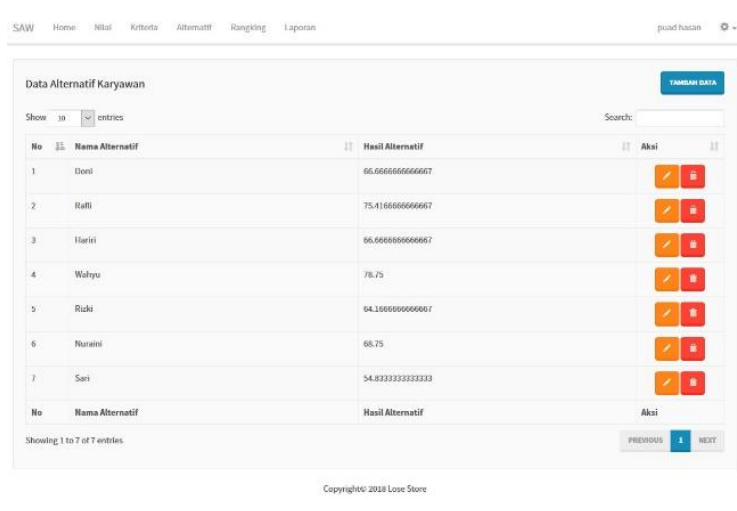

Gambar 4.10 Tampilan menu rangking

6. Menu laporan

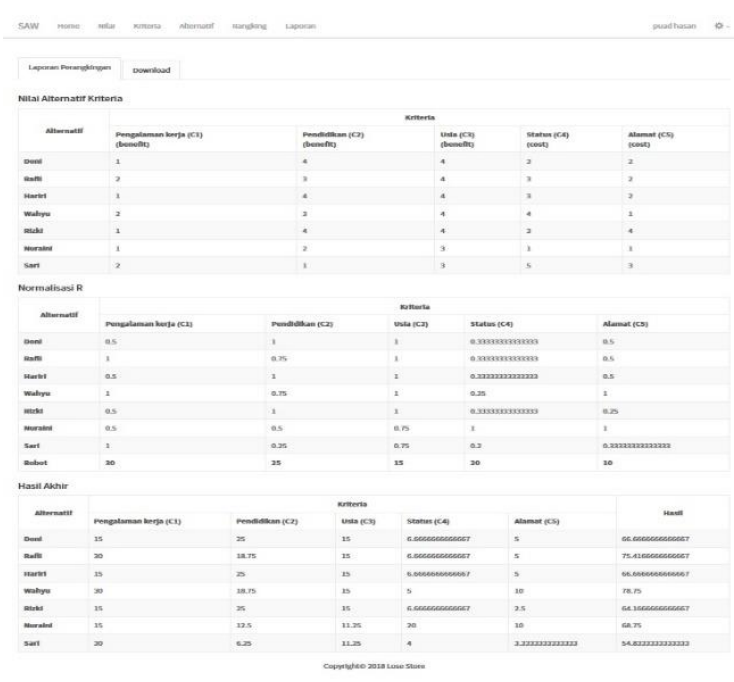

Gambar 4.11 Tampilan laporan

\section{KESIMPULAN}

Sistem pendukung keputusan penerimaan karyawan dengan menggunakan metode Simple Additive Weighting (SAW) salah satu solusi dalam menyelesaikan permasalahan penentuan karyawan baru secara terperinci. Dengan menerapkan kriteria-kriteria bisa dilakukan dengan lebih akurat dan tepat dalam menyeleksi karyawan baru. Berdasarkan penelitian yang dilakukan di Lose Store dapat di ambil beberapa kesimpulan bahwa :

1. Metode Simple Additive Weighting (SAW) mampu membantu dalam proses penerimaan karyawan baru.

2. Sistem yang sudah terkomputernisasi mempermudah kinerja Sumber Daya Manusia (SDM) dalam memperoleh karyawan baru.

3. Pemanfaatan teknologi informasi yang dipadukan dengan teknologi komputer dapat membantu perusahaan dalam pengambilan keputusan sehingga lebih akurat.

\section{REFERENSI}

[1] Anhar. (2010). Panduan Menguasai PHP dan MySQL secara otodidak. Jakarta: Media kita.

[2] Arief, M. R. (2011). Pemrograman Web Dinamis menggunakan PHP dan MySQL. Yogjakarta: ANDI.

[3] Bunfir, N. (2013). Dasar Pemrograman Web PHP MySQL dengan Dreamweaver. Yogyakarta: Gava Media.

[4] Fishburn, P. (1967). Additive Utilities with Incomplete Product set : Application to Priorities and Assignments.

[5] Handoko. (2008). Manajemen Personalia Sumber Daya Manusia. Yogjakarta: BPFE.

[6] Jogiyanto. (2014). Analisis dan Desain Sistem Informasi. Yogyakarta: Andi.

[7] Kartini. (2013). Perancangan Sistem Informasi Pemesanan Tiket Konser Musik Online Berbasis Lokasi. Yogjakarta: Semnasteknomedia.

[8] Kusrini. (2007). Konsep dan Aplikasi Sistem Pendukung Keputusan. Yogyakarta: Andi.

[9] Kusumadewi. (2006). Fuzzy Multi-Attribut Decision Making (FUZZYMADM). Yogyakarta: Graha Ilmu. 
[10] MacCrimmon, K. (1968). Decision Making among Multiple Atribut Alternatives : a survey and Consolidated Approach.

[11] Moekijat. (2010). Manajemen Sumber Daya Manusia. Bandung: Mandar Maju.

[12] Rohmat Taufiq, S. M. (2013). Sistem Informasi Manajemen. Yogjakarta: Graha Ilmu.

[13] Setia, B. I. (2014). Jago Pemograman PHP. Jakarta: Dunia Komputer.

[14] Shalahuddin. (2011). Modul Pembelajaran Rekayasa Perangkat Lunak (Terstrukur dan Berorientasi Objek). Bandung: Modula.

[15] Siswanti, S. (2015). Sistem Pendukung Keputusan. Yogyakarta: Graha Ilmu.

[16] Turban, E. A. (2011). Decision Support System and Intelligence System 7th. Printice Education International.

[17] Widodo Prabowo.P, D. (2011). Pemodelan Sistem Berorientasi Obyek Dengan UML. Yogyakarta: Graha Ilmu.

[18] Yoder, D. (2010). Manajemen Sumber Daya Manusia. Jakarta: Salemba Empat. 